\title{
From Gun Barrel to Passport: Smuggling on the Turkish-Syrian Border ${ }^{i}$
}

\author{
Ayşe Yıldırım \\ Department of Anthropology, Mehmet Akif Ersoy University, Turkey \\ *Corresponding Author: ayseyildirim@mehmetakif.edu.tr
}

Copyright $\bigcirc 2017$ by authors, all rights reserved. Authors agree that this article remains permanently open access under the terms of the Creative Commons Attribution License 4.0 International License

\begin{abstract}
Syria, which has witnessed a war that has been going on for many years now, is a country founded by the French after the Turkish War of Independence in the early 20th century, and the border between Turkey and Syria was drawn up during the French mandala. One of the characteristics of this border line-which is also valid for most of the newly-founded Middle-Eastern and African nation-states - is that historic and ethnic continuities have not been calculated, and that it was drawn up as if with a ruler. This characteristic has revealed various border fancies in terms of the states with political borders and the people or groups living on the border line. Undoubtedly, one of the areas in which political borders are visualized differently by the state and the border people is the cross-border trade. In this study, the economic action, defined from the perspective of the state as 'smuggling' between Nusaybin, a county in Mardin and the city of Qamishli in Syria, which are situated oppositely in the Turkish-Syrian border region, has been handled. The conversion of land, which has a traditional use value, into a territory for modern states, can problematize a 'natural' economic activity by making it 'illegal'.
\end{abstract}

Keywords Border, Smuggling, Turkey, Syria

\section{Introduction}

The Turkey-Syria border, which was determined during the Treaty of Ankara signed on 20 October 1921, constitutes Turkey's longest land border with $877 \mathrm{~km}$. The realization of the basic form of the border takes place on June 23, 1939 when Hatay joins the borders of Turkey. Through these agreements, two separate nation-states, which are part of a multi-ethnic empire (the Ottoman Empire), have been created. However, the nation-states which took the place of the multi-ethnic empires in the Middle East emphasize the notions of sovereignty and borders they adopted from the West although these notions are incompatible with their actions. It is seen that most of these borders are artificial borders and ethnic groups living in the region have not been taken into consideration. This has frequently led to an ethnic group often staying within the borders of more than one country. On the contrary, in the relations of kinship that existed in the forms of social organizations, as in the tribe, there was no break in spite of the borders. It is possible to talk about this kind of connection between Nusaybin and Qamishli on the border between Turkey and Syria. In this context, one of the dynamics that provides the continuity of the relations between the two cities is exchange and commercial relations.

The data for the study are based on a field survey conducted between 2010 and 2011. Following this data, how kinship was used in smuggling and exchange which had become a part of daily life with the new borders between Nusaybin and Qamishli, how it affected them, and the border crossings have been discussed. The study also reveals the historical development of border trade, especially through oral history data (which emphasize local experiences).

\section{Background}

Nusaybin has been a historically important economic center due to its location on the ancient roads stretching from Mesopotamia to Anatolia and from Asia to Syria. For instance, from the city which had been the border town of the Roman-Iranian struggle from the III $^{\text {th }}$ century to the VII ${ }^{\text {th }}$ century, and which takes place in the sources of that period with the name Nisibis, is mentioned as "the first gate through which trade exchange was realized between the two empires and the first gate of the Eastern merchants that opened to the West." During this time, Nusaybin was rebuilt each time despite the fact that it changed hands many times between the two empires (Roman-Persian / Byzantine-Sasanian) and suffered great devastations.[1] It continued to be mentioned as an important trade transit point although it lost its feature of being a border town since it had been included in the inner regions during the Ottoman period. [2] When it came to the 1900s, the maps of the period first showed Iraq, Turkey, and Syria as three new nation-states separated by international borders. Thus, Nusaybin became a border town once again 
by being divided between Syria and Turkey.

These new borders, drawn at the beginning of the 20th century, have had significant political, administrative, economic, and demographic impacts (such as national soils and new sovereignty areas) on local people living in the region. Considering that the economic structure and relations are closely related to the physical geography in particular, it can be seen that the borders sometimes bring about many changes, especially the existing livelihood pattern. Likewise, the separation of the "inner" regions of the Ottoman Empire from each other by borders leads to the removal of certain economic regions. In this context, Zafer Toprak [3] points out that the contraction of the size of the country's land means the contraction of the domestic economic area and emphasizes that the political borders and the economic borders do not overlap. For instance, the natural economic extensions of the Southeastern Anatolia region which was closed to the north due to the Taurus Mountains with the proclamation of the republic remain in the territories of Syria and Iraq. Moreover, the differences caused by political and economic borders, change the fluidity of production factors and lead to narrowing of regional markets in practice. Karpat [4] notes that "the indiscriminate drawing of the borders, the villages and towns on both sides of the border, almost consciously cut their links with the economic and geographical centers left in other countries.

Undoubtedly, this feature of the new borders mostly affected the groups that have immigrant livestock economic life style and use large areas for this activity. Three residential districts consisting of Kobani, Kurd Mountain, and El-Haseke provinces which make up the northern border of present-day Syria at the same time constitute the natural extension of the Kurdish regions in Turkey and Iraq. In particular the Jazeera region, which is more fertile when compared to the others, has been an area where Kurdish nomadic tribes and Arab Bedouins who have spent part of the winter in this warm region for many years and which gave tax to the Bedouin Shammer tribe until the end of the 19th century practiced their pasture activities. In the Ottoman period, the nomadic Arabic tribes Shammer, Tayy and Bakkarej grazed their camels in this region, and the region remained the main area where the Kurdish tribes such as the semi-nomadic Milli, Dakkori, Miran and Hevêrkan grazed their herds and spent their winter.

The fact that the new borders of Turkey, Syria, and Iraq pass through the middle of the tribal lands results in the summer grasslands of many nomadic tribes remaining on the one side of the border and their winter quarters remaining on the other side. Bruinessen [5] notes that there are two options in front of the tribes facing this situation. The first is to change the migration routes if they can find new pastures, and the second is to adopt a sedentary life. When the difficulty of finding new grasslands is taken into consideration, adopting a sedentary life becomes an alternative that must be preferred. Thus, some tribes that have become unable to fully implement their annual migration routines settle down south of the border. For example, an important part of the Botan migrants, who spend their winter in a thin strip extending just north of the border of Syria and Iraq, remain in Turkey where summer pastures are located. Miran tribe can no longer migrate due to the closure of the Turkish-Syrian border. Bruinessen [5] states that the Miran were settled in the former winter barracks, Syrian Jazeera, due to political reasons (fear of the sanctions of the new state), and that they had begun to cultivate because their ties were severed with Diyarbakır villagers from whom they traditionally bought wheat. However, migrations from Turkey to Jazeera continued for a long period of time; for example, many tribes affiliated with the Hevêrkan confederation founded approximately 40 villages in Jazeera by migrating to this region in the leadership of Haco Ağa. Thus, while the new borders forced many tribes to settle down, resulting in significant changes in economic structures, they also caused "contraction of regional markets."'[3]

On the other hand, the permanent settlement of migrants in Turkey has accelerated especially in the 1950 s, as the remaining winter pastures have begun to be inadequate. [5] Beşikçi [6] transfers one of the examples of this new situation. Besikci, in his work on the Alikan tribe, one of the tribes of the Hevêrkan confederation, recorded that as a result of the facts that the land required for movement to the tribal population in the traditional case was adequate and that the Iraqi, Iranian and Syrian borders were open to the nomadic movements, they could lodge on whichever highland or winter quarter they liked. Nonetheless, the rapid increase of the population, the increase of the number of people controlling the land, the closure of the borders of Iran, Iraq, and Syria narrowed the area of the tribal movement and increased the value of land and its price at the same time. ${ }^{1}$

Nevertheless, it is also necessary to indicate that despite the political borders, border crossings are not completely closed down in this period. Especially people staying on the other side of the border will continue to carry out cross-border agricultural activities for a while with documents called transires in certain periods of the year. In this context, in his speech on October 16, 1921, İbrahim Bey, Deputy of Mardin, who carried the destructive effects of the borders for the people of the region to the agenda of the period, expressed his dissatisfaction with the fact that the physical conditions of the border town of Nusaybin were not suitable for agriculture, and for this reason he talks about the essentiality of the continuity of cross-border agriculture for the economic structure of the people of the region. [7] For this reason, transire crossings continued for a long time between the two countries; however, they came to an end with Turkey's confiscation of the Syrian lands within her own borders with the decree dated October 1, 1966 and numbered \&/7104 as a retaliation to the decision of

\footnotetext{
${ }^{1}$ For a study which discusses all the effects of the borders on the nomadic tribes, see Tapper 2004 .
} 
confiscation $^{2}$ to the lands aforementioned in consequence of Syria's land reform dated 1958.

In addition to the fact that boundaries necessitate transition from nomadic life to settled life, another element that supports settlement in the land is the government's housing policies. For example, in 1985, 191 immigrant families belonging to the Düdiran-Kiçan tribe in the province of Idil were subjected to urban resettlement.[7] In the 1980s, the nomadism had almost come to an end with the Kurdish movement. However, the period after the 80s did not only remove nomadism and its associated lifestyle, but also seriously harmed the traditional form of production based on agriculture and livestock that resulted from forced migration by evacuation of villages.

Finally, the economy has set its own line, and the cross-border economic relations including "smuggling" have begun to gain importance as the economic policy have been unstable and biased since the beginning of the state in relation to the regional economy. Rather than the legal trade, the smuggling-dominant structure was the lifeblood of the economy until the emergence of the Kurdish movement in 1984. The emergence of the Kurdish movement has been influential in border crossings and has caused smuggling to become a more risky act with a meaning including its commemoration with the Kurdish movement.

\section{3. "Smuggling:" According to Whom, According to What?}

Even though defining borders or border relations are not contemporary matters of fact, they have gained new senses and have been rebuilt with the former state forms leaving their place to other forms - especially with the appearance of a new understanding of hegemony. In today's world, social, economic, and political life cannot be regulated without boundaries. When we think about border and economic relations, illegal trade ("smuggling") expressing a disruption especially for the states confronts us. According to Donnan and Wilson [9] borders and smuggling have been defined relative to each other to a certain degree. By definition, for smuggling to be identified as such, there has to be borders and the state has to declare which goods are allowed to be imported and exported legally. Therefore, the illegal evaluation and punishment of the commercial rituals between any two regions, called "smuggling," came into existence with the emergence of state borders. Price (qtd. in [9]) stresses in this context that smuggling is a crime against the state rather than a crime committed against the individual or against his/her property. According to him, smuggling is

\footnotetext{
${ }^{2}$ For example, the land reform in Syria was included in the Turkish pres as follows: "Syria confiscates Turkish lands: The Syrian government confiscated the territories belonging to Turks in Syria. Lands in the 60 villages of Turks in Nusaybin and Mardin have been taken from them under the name of land reform. Our citizens travelling from Turkey to Syria were not allowed to step on the confiscated lands and they returned home." [8]
}

not observed in small-scale societies, which can take measures for the flow of illegal goods and lack the common and legal expression of social interests. On the contrary, smuggling is only found in political units organized in the form of state.

Baud and Schendel [10], who define smuggling as a typical border action in which politics and economics are together, argue that states try to restrict border trade by law. However, when the people living in the border region oppose these laws and make them inapplicable, the action defined as smuggling occurs. For states, the aim of these restrictions is usually to take advantage of the tax on certain products. Cross-border trade, which is accepted as illegal by the legislation, may only be an extension of existing trade. However, smuggling is often the result of restrictive state policies, which cause some goods to be scarce, attractive, or expensive.

Sikder [11], who examines the informal trade on the borders of Bangladesh, notes that despite the fact that smuggling is accepted as illegal by the states, this trade is necessary for the poor people living in the border regions to survive and that the illegal border trade has developed because the state fails to meet the needs of the poor. Baud and Schendel [10] also emphasize a similar issue and further draw attention to the significance of kinship on both sides of the border. Accordingly, in many cases where governments fail to tackle the border economy with the national economy, people living on the border have no other chance. At the present time, cross-border commercial activities are based on networks such as previous kinship, and friendship which are spread across both sides of the border.

Trade and exchange between Nusaybin and Qamishli constitutes one of the examples of cross-border trade activities carried out through ethnic networks and kinship ties on both sides of the border. As it has been stated above in the background, Nusaybin, an interior region in the Ottoman period, was more dependent on some centers in the Middle East than in the West. Nevertheless, while the new borders forced Nusaybin to merge with the western regions of Turkey by separating it from the economic centers that it was connected to, Syria endeavoured to include the newly-founded Qamishli in her own inner regions. Mesut Yeğen [12] summarizes this process as follows:

One of the important consequences of the collapse of the Ottoman Empire is the division of Kurdistan. The clash between the imperialist forces of the period resulted in a "consensus" about the division of Kurdistan into three parts. The emergence of three different economic units (Turkey, Iraq, and Syria) from a single economic unit destroyed economic relations based on empire logic. In short, the economic integration of Kurdistan during the Ottoman period and the administrative reforms initiated in this period, have gone to a new stage after the division of Kurdish lands by "national borders." Each economic unit, or more precisely each new nation-state entered into an effort to 
create "a national economy" within its own borders. In the case of Turkey, the Kurds wanted to be integrated into economic centers such as Istanbul and Izmir. This meant the destruction of the traditional economic networks of the Kurds. Prior to the collapse of the empire, the centers of the traditional Kurdish economy consisted of cities like Aleppo, Damascus and Baghdad in the Middle East. However, with the collapse of the empire, these centers were declared the "other side" of the border. As a result, the "normal" economic activities of the Kurds, where national borders are divided between Turkey, Iraq and Syria, are regarded as smuggling.

Bruinessen states in Aga, Sheikh, State [13] that smuggling is a new profession that emerges with the borders drawn:

In countries where various parts of Kurdistan were located, the price of tobacco, luxury goods and meat changed so much and it was not always possible to find all of them. This situation and the lack of cash-generating job opportunities in Kurdistan have made smuggling one of the pillars of the Kurdish economy. It is not possible to calculate the contribution of smuggling to the "national income" of Kurdistan. Yet, I can make a little brave guess and say that it is in the third place after agriculture and animal husbandry.

According to a controversial claim that poses a different point of view, smuggling also refers to a "reaction" at the same time. Bozarslan [14] asserts that just as the rejection of the practices imposed by the madrasa or "irreligious regime," customs smuggling is an argument that the civilian resistance of the opposition is visible in rural areas. As for Yeğen [12], he says that smuggling outside national borders has become an important part of Kurdish economy. According to him, the continuation of smuggling points to the sensitivity of the Kurds on their history and traditions. In this context, smuggling involves an ethnic emphasis and is, in fact, a challenge to the nation-state construction project. However, this does not mean that the Kurds have consciously established their own national economies. On the contrary, it is a reaction against the Turkification/nationalization of a non-national (a-national) economic area.

Besikçi [6] argues that since barter trade of the goods is in question in the cross-border exchange trades, a commercial purpose cannot be uttered; therefore the borders remain on paper only. Certainly this thesis of Beşikçi is valid for the early periods when the borderline was drawn. The two cities have become dependent on each other both due to their economic continuity and different developing economies. For this reason, the economic exchange between Nusaybin and Qamishli, which is regarded as smuggling, has emerged due to mutual requirements between the two cities. For example, in the interview made with the woman who reports that she smuggled in the region the exchange of goods that Beşikçi [6] mentions draws the attention: "Now I know how many houses there are in which garden on the Qamishli side.
I would take the donkeys 3 times a day to Qamishli to exchange wood for bulgur. I would return home to make bread and cook." In the following years, however, this form of exchange has undergone a significant qualitative transformation and has enabled the flow of high-value goods. Therefore, while at the beginning mutual barter trade was based on basic needs; later developments have given commercial importance to this form of exchange.

Starting from these arguments, it is problematic to define trade and exchange between Nusaybin and Qamishli as smuggling at least for the local people dealing with this business. Even though the dominant discourse is settled today, this action is not called smuggling by the people who deal with it. The concept used in local discourse is to hit the "border." Therefore, this economic activity, which takes place between Nusaybin and Qamishli and is defined as "smuggling," is from a statist perspective. Donnan and Wilson [9] warn about the issue that "to name the across-border trade which is carried out secretly as smuggling may carry the danger of the adoption of a statist perspective which can fall into disagreement with the perception of those who deal with such business closely and who evaluate their own economic activities as rightful."

As a result, the main problem has arisen here with the transformation of the soil into a territory. The land, which is a habitat for the local people, is for the nation-states a territory the borders of which must be defined and protected. Insistence on maintaining the traditional economic relations for people who have begun to live within the borders of two different countries with ethnic continuity harms the state's enforcement of law as a unitary corporation and its imagination of order encapsulating the territory, as Schendel [15] also states.

However, to say that the reason for trade is only this link, for example, is insufficient to explain why smuggling is found in areas that do not have ethnic networks. Especially trade with places close to settlements near the border is more advantageous than trade with the inner regions because border regions have always been seen as areas of economic opportunity. The factors such as the tax exemption of illegal goods, the distance between two settlements is shorter than that of the inner areas (for example, between Nusaybin and Qamishli is about one kilometer), so that the transportation fee is lower, make it possible for the smuggling to be carried out. In addition, smuggling is not only an opportunity for local people, but also an opportunity for those in the region, especially those in military and similar positions.

The following sections of the study will focus on two forms of smuggling. The first of these is the trade in suitcases which occurs with more control, and the other is smuggling, which pushes the border in general.

\section{Local Organization of Smuggling}

\subsection{To Hit the Border}

Smuggling, exhibiting a historically different form of 
organization, requires that a group be organized in a process that runs from the crossing of fugitive goods to the distribution of local or national market, rather than being an event that can be carried out on its own. As a result of the negotiations, it became clear that a large number of actor types took part in this trade. Although each of these actors has a different role, each group is functionally related to another at the same time.

Porters: The first form of smuggling that emerged with new borders is porterage. A porter is a person who carries goods across the border at his own expense with a small amount of capital. Bruinessen [12] points to the place of porterage in Kurdish social organization, stating that back-smuggling has an attenuating effect on tribal ties because it is an economic action that can be done individually. However, the thickening of the borders brought an end to porterage that can be carried out individually. After this period, rêzans and contracted crossings have begun to gain importance. While the mine field promoted the importance of rêzans who are specialized in border crossings, large-scale smuggling began to be carried out based on agreement with the border officers, resulting in economic and political power being gathered in the hands of two groups that organized negotiated transitions. Among these, the first one is the agas (landlords) as an already distinguished group, and the second is a new class of entrepreneurs. A new patronage relationship has developed with ordinary smugglers working with these people.

Rêzans: The main group organizing illegal border crossings are the so-called rêzans who are also named as "smuggler leaders." A rêzan is a kind of border guide that takes the order from both sides of the border, without any capital investment, and leads the group to clear the mines on the path in the passage way, which leads to the safe submission of the goods, in other words to intermediate the trade between the two countries. Everyone in this trade network knows each other in the region. For this reason, the rêzans receive orders from merchants located in the area extending from Syria and Nusaybin to Diyarbakir in the region. All processes, from the order of the good to its delivery to the merchant, are managed by rêzans. Therefore, rêzans not only help the caravans pass through the border, but also they are sometimes obliged to transport them to an area extending to Diyarbakır. This obligation is based on agreement. In addition, those who make the agreement with soldiers in the allowed (agreed) crossings are mostly rêzans.

Those who know the borders well are the guides here. They know very well where is a mine or where is clean. They rent them, what they call rêzan, with money. For example, they would say we're gonna set out at 1 a.m. They all usually wear black clothes. Now that the colour white is noticeable, it is never worn. Then, in single file, with a monotype appearance they cross the border (from Nusaybin, male, in his 40s).

Below, three profiles of smugglers will be included. The first of these profiles related to a female smuggler who is said to be over 100 years old. The feature of the period in which the woman smuggled is that it corresponds to the first years when the borders had just been drawn and when the border line was being tried to be clarified with wire fences. Therefore, border crossings were relatively more comfortable. The two other examples are about rêzans. The importance of the years that rêzans came into focus and gained significance is that the boundaries began to thicken and the border crossings became risky, creating a specialized business group. Topics such as the characteristics of rêzans, their social relations, the form of transition, and the economic structure of the period will be discussed through these profiles. Moreover, it is also important to note that the important actors seen in smuggling are also evident in the profile of rêzan.

\section{Example 1}

The female smuggler is from a mountain village originally affiliated to the Gercüş district of Batman, that is, she is from one of the Torîs. ${ }^{3}$ She immigrated to Nusaybin after she got married. When she was a village headman in Nusaybin, police stations began to be built and she developed a good relationship with the military. In the period when the woman smuggled, bartering of goods mattered. For example, she stated that she took wood from Nusaybin to Qamishli and took foodstuff in exchange within the same day. Moreover, all the needs such as oil, rice, and bulgur were supplied from Qamishli. In other words, this form of exchange was a regular part of everyday life.

The good relationship she has developed with the soldiers ensures that she can easily come to and leave Qamishli, and even, most of the time, the troops protect her. However, this cannot be said for all soldiers. The woman could sometimes use these relationships to turn the situation in her favour. One experience that the female smuggler shared is as follows:

Once my guests arrived in the mid-afternoon and said "there is some money that we need to take to Syria." I said, "I am alone, it is mid-afternoon." In today's money it was 40-50 thousand liras (then 40-50 billion) and I was alone. They insisted on it, and I accepted. I took a headscarf and put it on the ground, put the money it, and tied it to my body under my dress. I put on my cloak and went out. I arrived at the police station. The master sergeant asked "Where are you going to?" I said "I have some guests; I have to drop over Qamishli. But I am not going to stay there, for your information." $\mathrm{He}$ said "mother, come under the well when it is over, wave your hand once you do, I will send someone to pick you up." I proceeded on my way and I arrived at the house of one of my relatives in Cirmıke. I said "send your son with me until Qamishli, let him come with me. My relative said "my son is not home." "I am going now," I

\footnotetext{
${ }^{3}$ While Torî means mountain villages, çolî indicates lowland villages
} 
said, "but when your son returns tell him to wait for me on the Anteri bridge, I may return late, tell him to meet me there." I went to Qamishli and exchanged the money.

\section{Example 2}

Ahmet was a rêzan in 1956 when rêzans began to gain importance due the fact that the borders began to thicken. His reliability and the fact that he accomplished the jobs he took by demining the mines with expertise enabled him to become a person preferred by the merchants in Nusaybin and Qamishli. He has many stories of courage ${ }^{4}$ to tell such as how he robbed the granaries in the train station of the state of Syria by emptying them, how he was involved in a gunfight with soldiers, and how he removed the mines. For example, he shared that he was called "Ahmet the famous smuggler" on the Turkish side, and as for Qamishli, as he told, "their mothers would scare their children who wouldn't go to sleep by mentioning me: 'go to sleep or Ahmet will come and take you" they would say, to express how legendary he was.

Back in the old days, when there were no doors, they would come like this with 70-80 and sometimes with 120 horses without riders to Syria and buy goods. Then, they would say "make us cross the border." In those times I would take 200 liras per horse. Hazro, Diyarbakır's borough, is about 300-350 km far from here. I would pursue those horses from the mountains on foot and take them as far as Lice, Hazro. For example, I would reach a village near Midyat in one night, and in another night I would arrive at Batman. Another night, I would bring 50 horses to Hazro on foot.

I'm not allowed to get in Syria. If I get caught, they will put me in jail. Whenever I went to Syria, I would hide in my partner's house. I would take the horses to Syria without any riders. I would hide them, too. Then, I would write a note on a paper and say "take this to a certain shop owner and tell him to come to me, we must meet up." The shop owner would come to the village that I stay in. The horses would of course be in Syria. We surely would have horse owners, too, with us. For instance, let's say the horse owner is Ahmet. "Ahmet, how much load will you take on?" He would say "I will take 5 loads of carpets." Then, the other would say I will take 10 loads, Hasan says 2 loads. Seyit and Ali say they will take 1 load. In this way, the loads of 100 horses would be completed. After that, the goods would come from Aleppo (Halep) and Damascus (Sam) by car at night; they would be taken near the border. I would ask "how many loads have you brought?" He would say "I brought Ali's 2 loads, Mehmet's 10 loads, Hüseyin's 3 loads." They would load the horses, we would tightly tie them. I would pass them through the mines into Turkey.

I would first check to see if there were any soldiers or not. Of course, I had a gun. After making sure that there were no

\footnotetext{
${ }^{4}$ However, Özgen [16] notes that border crossings are generally agreed (negotiated) although rêzans are often referred to as gaudy and valiant persons and their masculine traits are emphasized.
}

soldiers, I would take out the mines. After taking them out, I would make the horses pass into Turkey. Then, we would take the horses to the mountains. They would spend the night on the mountains. During the day I would rest. The following night I would gird on my gun and follow the horses. For example, we would go as far as Midyat in the first night, as far as the borough of Batman (then it was a borough) the following night, as far as Lice, Hazro the other night, for about 4-5 nights in total on foot. I would take the horses wherever the owner of the horses would ask me to. To make the horses cross the border I would take 200 liras per horse; and if it had to be as far as Lice, Hazro, I would take about 300-500 liras.

In those times, they would get carpets, I mean wall gobelins, beads, fabrics, Swiss fabrics, Japanese fabrics, velvet across the border from Syria into Turkey.

What Ahmet shared shows that there is another group who work with rêzans. They are the horse owners. The horse owners can from time to time be people who take the orders of the merchants for a fee, and sometimes be the merchant himself. When the smuggled goods get caught here, the loss is personal. Moreover, the expanse of the border's sphere of influence is also understood. The good that is brought from the other side of the border is sold not only in Nusaybin but also in a region stretching as far as Diyarbakır.

Another group is the carriers. Carriers are people who carry the smuggled goods with their body (on their backs) for a fee. They keep the contraband in their own houses until they submit it to the owner. They do not have a share out of profit.

For example the youngsters say "I am poor." I was getting them across Syria. If I took two loads, I would give one to them. They had with them a document. Then, they would hide them in their houses. The other night the grocers of Nusaybin would come, take their loads; sell them in their grocery stores. We would sometimes go with permission and sometimes without permission. When we went with permission, if there was a soldier or a commander, we would pay them some money. For instance, then, it was 10 liras, 20 liras for each horse. We would hire a carrier; for example we would hire 50 carriers. We would pay each carrier. There was no horse then, I mean, when we hired carriers, they would carry the loads on their backs and we would thus get across. First there were horses, for instance one sheep, cow, bull, we would take them too.

Reliability is of utmost importance in rêzanship. What provides reliability is courage and permanence. Ahmet's gaining the trust of the people in the region, causes not only the merchants, but also anyone who wanted to cross the border in those times - for example, the convicts - to consult him. One of them was Koçero, who was among the famous bandits of the time. ${ }^{5}$

\footnotetext{
5 Koçero is actually a farmer from Silvan. He killed the aga's son because of a hostility between him and his son. He then takes his wife and four children and goes to the South, to Syria. Kocero, who left his family in Syria according to the accounts, has frequently entered Turkey from the border for
} 
Then, convicts also began to trust me. Koçero, and here there was also Kara Ali (Ali the Black) for instance, they would come to me, too. Koçero had shot many people in the village case, and he was going to escape to Syria. In those times, convicts would always escape there. Koçero would say "I don't trust anybody. I only trust Ahmet. He can get me across the border no matter what. He can take me, my family to Syria across the border.

The period between the years of 1940 and 1950 shows another dimension of the illegal crossings. The economic conditions of the period which was described as "famine years" [14] for the border public paved the way to the eastward migration of illegal workers including women. Especially in the 1940's, many people from the Southeastern Anatolia, especially Mardin, went to Lebanon - mainly to Beirut - via Syria illegally. ${ }^{6}$ Numerous workers migrated to Beirut from Nusaybin by illegal means. Ahmet got the people who wanted to go to Lebanon ${ }^{7}$ illegally across the border:

Back in the day people would go to Beirut. There was famine in Turkey; they would go and work in Beirut. They would work there 4 or 5 years and save some money, and then come back. They were coming from Batman, from Lice of Diyarbakır, from Hazro, or from Midyat. Since the people trusted me, they would come to me. Surely, crossing the border was difficult, there were mines, no one could manage. I would get them across to Syria with difficulty. Every night 2 or 3 buses of people would come. In the evenings, I could not even eat anything because of anxiety; I would ask myself "how am I going to get them across the border?" While I was thinking so, suddenly I would decide and say "well, tonight I will hit the border; I will take the mines there and get this caravan across." For instance, there was no work in Mardin, Kızıltepe, Batman, or Eğil. There were so many in Beirut. I mean, one would wallow in money; they would pay you so much money. I didn't see Beirut myself, but that's what people were saying. People there are for the most part Assyrian. And the Assyrians are rich people. For example, women do not work there; they would ask for charladies from here; they would say work for me, and they would pay a lot of money. In those times, there was famine in Turkey, that is, there was no work here. Girls like you would come to me; I would get them across the border. They would go to Beirut and stay there for 2 or 3 months, and would bring back gold from here to here (showing his forearm).

Among Ahmet's experiences, there are also his relations

banditry. In those times, anyone who had problems (such as avoiding military service and punishment) with the state fled to Syria in a way. [17] ${ }^{6}$ It has been reported in the document dated 2010 published by ORSAM that 20 thousand of the population living in Beirut migrated from Turkey's Southeast Region

It has been reported in a newspaper dated 1975 that a large number of Turkish workers who went to Lebanon from illegal roads without passports entered Turkey from the Nusaybin gate. [18] with the soldiers on the border and the crossings based on agreement. However, while it is possible to come to an agreement with certain soldiers for allowed crossings, certain others makes the border crossings difficult. The allowed crossings set forth the role of the border guards in smuggling and their ambiguous attitude:

I wouldn't always cross the border fugitively. It would sometimes be allowed. For example, there was a Lieutenant N. I was working with him under an agreement. I would see the battalion commander, and the battalion commander would see the regiment commander. Lieutenant N. Left the army; he is in İstanbul, dealing with trade. Some of them would make it difficult. There was Ş. , he is still alive, and he is now a brigade commander. He wouldn't accept a bribe here. When he came here, he began to shoot the smugglers. He once laid an ambush to get me. One day soldiers came to my house. They said "Brother Ahmet, smuggle 200-300 horses, we will take them." There was Sergeant Hamit, he came downtown and said "I will see Ahmet." We sat at the coffee house. And Ş. was then a squadron leader. Sergeant Hamit said, "Look, don't get closer, S. was sent here to shoot people. Don't you ever trust him." I said "I don't." One day Nevzat came. He said "Find and bring 150 horses and I will get you across." Then one night, my mother, me, and my cousin were returning from my uncle's house. I was wearing a suit. It was midnight. A car stopped by our side and Ş. was inside. He said "Ahmet we have heard that you are going to get 150 horses across." N. was then a battalion commander, and people said that Ş. was going to replace him. I said “well, it's a lie, I wouldn't. You see everything; I have a suit on me. I am going home now, it is midnight." Then he said "come" to me. He got me in his car. They took me away alongside the wire. He said "You are going to swear to give up, you are going to leave the border." "I promise," I said "I will swear." I didn't, of course; I went on hitting the border. Then he came and took me again and he blowed me with the bastinado.

Sometimes I would see the battalion commander [I would give him money]. Sometimes, I would first give money to soldiers; sometimes I would get across fugitively. I would take the mines from the border, and cross. I knew where they were. I still know on which path there are mines, and on which there is none.

When I hit the border, sometimes there would be a gunfight. I sometimes fought with the Syrian soldiers, and with the Turkish soldiers, too. I had a gun. Since I was the leader of smugglers, a gun was a must.

Sometimes the soldiers would see me on the border and would ask "aren't you Ahmet?" I would say yes. They would never react, they were afraid. I would violate the border.

Ahmet got caught once, got fined and gave up smuggling. In the present day, he is among the rich people of Nusaybin 
and he has shops in the Smugglers Market, a dashy house, and cars.

\section{Example 3}

Mustafa, another smuggler, began smuggling when he was 13 by his father's side who was a rêzan. He explains the reason for his smuggling as follows: "We didn't attend the school; there was no school in the village then. We didn't work with digging tools, either; that is, we weren't used to. We don't have any fields, either, we have nothing; what are we supposed to do? Most of us are in this situation. What can you do when there is nothing?" However, Mustafa was not as lucky as Ahmet in smuggling. He smuggled for about 30 years, and in this while, he got caught for 3 times and got prison sentence. In the present day, he has quitted smuggling; however, he did not make any savings: "I worked for a very long time at the border but I guess the money was not halal, I don't know, I didn't earn anything. I just saved the day, I can say."

I was only 13 when I started smuggling. Now I am 50 . We would go smuggling with horses. There were wire fences but they weren't too high. I mean, the fence consisted of one line of wire. We would step 30 steps and then look for mines. In every 30 step there would be a mine. There were two lines of mines. There used to be another line of wire across the first wire but the smugglers had removed it; there was only one left. Yes, the one on the Turkish side. It has been about 10-15 years since they strung the wire across. The first wire was already there; they built the wire across later. The smugglers would remove the mines and sell them in Syria. For example, we would find bullets, bullets used in hunting, they would sell them. They would be sold to blacksmiths; they would buy them to make fishing rods with them. Today, there are still mines, but in certain places there are none left. But in some places there are still many; for example, in the areas close to the police stations, there are mines. Yet, for instance, there is a stream; there is none left there. On the border, there was a police station on every $5 \mathrm{~km}$. Still there are. After you leave Nusaybin, soon there is a turnout to Mardin, it is the 30 . $\mathrm{km}$; there were 6 police stations there.

Now they built wires between those two lines of wires thoroughly. But before, there was neither that road, nor the first wire. They built the wires in Tansu Çiller's time. While we were crossing the wires, we would take a wooden board and put it on the wire and then cross. That wire is flexible but it is also razor-sharp. It cuts you once you touch it. When that wire wasn't there, we would go with horses, and we would bring back tea, cigarette, and shawl from Syria.

We would usually set out from here without any loads but for a couple of times we took animals with us. Yet, most of the time, we would go there without loads and return loaded. There would be tea, packages, tobacco leaves, especially Beirut leaves; we would bring them. Beirut leaves were very fine, very thin. Now it is not possible to find them. We would also bring tea glasses, 63 pieces (fork and knife sets); that is, we brought a variety of stuff from there. We would bring fabrics, clothes, jackets, and tin. We were partners with my uncle in that tin business. We would bring it from there and sell it in Midyat.

It has been previously stated in Ahmet's example that the first condition of being a good rêzan is reliability. This indicates that rêzan has to be a reliable individual. However, another important point regarding reliability shows itself in the matter of partnership. Despite exceptions, kinship and ethnic ties are used in partnership as in legal trade. Özgen [16] emphasizes two characteristics of partnership in smuggling especially until the 1950s. The first is that partnership is possible between persons who mainly have similar conditions; that is, they should be from the same ethnic or kinship group, from the same village, and have similar amount of care for livelihood. As for the second one, an alliance in which the trade to be done can be more convenient and productive is preferred.

All the village people are Kurdish like us; there are relatives, acquaintances, and partners. We would stay in the village. We would choose our partner from among the reliable ones. No, not necessarily a relative; whoever was hardworking on the border, whoever was reliable, I mean whoever we trusted, we chose him as our partner. But only Kurds did it anyway. For example, I met an Arab who did it. Arabs are very treacherous. They are no good. But there was one among them who was very reliable. Once, there was a police station in this Cizre region. A lieutenant was in charge of the station. Once we went and saw the goods an Arab had brought to us. He was reliable; I am not sure about the others. He brought to us one truck of goods: six thousand cartons of cigarette, six tons of tea. The Arab brought those goods to the border with a truck. The lieutenant did not picket any soldiers; he had an agreement. We gave him ten thousand dollars. It was 6 years ago, not more than that. We took the goods from about Cizre and brought it to Nusaybin. We put it in a basement, and then sold it all.

Another platform on which ethnic networks are used is commerce. In the present day, the relations developed within ethnic groups have made it possible to buy or sell with future-dated payments, as in ant trading. However, at this point, the negative side of social capital becomes visible. The negative side of social capital is that it can be dismissive especially within general and special networks. [19] While the social capital made it easier for those who took place in these networks due to the trust factor to deal with trade, it also causes the individual to be pushed out of this trade network in the cases in which the trust factor is lost:

We have relatives who are all acquaintances and Kurds like us. We would buy from the downtown in Qamishli. They were all acquaintances. If we had the money then, we would give it; if we didn't, the trust between us was there; that is, he would give us the good, and when we got back, we would pay the money. Of course, you wouldn't give the goods to anyone. Trust was a must. If one is unreliable, commerce is over.

Social capital is also used in overcoming many risky 
situations in smuggling. Here, the networks built by the relatives and friends in Qamishli are capitalized:

In Syria they would catch some of them. We had many relatives there. I got caught in there, too, for a couple of times, but they let me go. They didn't take me to the station. No, we didn't bribe them but our man was forceful. Once I got there armed. There was a soldier before me, so I went back. Then, I took one of my friends there. I saw the same soldier and started to run. My friend asked why I was running and I answered that I didn't want to get caught. He said "well, he is our friend, relax." We had a carrier with us and I had a rifle, yet the soldier told me to pass.

Lastly, the thickening of the border increases the risk in smuggling. The crossings which are not agreed are highly dangerous. There are a number of narratives regarding the smugglers who were wounded or killed ${ }^{8}$ during the crossings both in Nusaybin and Qamishli. It has been transferred that, in the case of a physical injury during a gunfight, the hospital would not be visited for fear that the smuggler could get caught; instead the response would be given either individually or within the kinship network. The experiences illustrate the individual response and how the kinship networks are used:

Well, there is camera on the border. That is to say, if 9 or 10 people are going, it catches the sight of them. There is camera in every high point and they are thermal cameras. If there are 1 or 2 people, and if they are moving along the stream, it is fine; yet, if there are more people, it certainly catches their sight. A lot of people died on mines; that is, the mine would explode while removing. No one could escape when that was the case. In some cases, we would not notice the soldier but he would see us and shoot. The first bullet that was fired would kill the smugglers; but then, after the first shoot, we were armed, too, you know. Since the soldier was

\footnotetext{
${ }^{8}$ If the smugglers are dead, if there is no such thing as mentioned above, the soldiers find the corpses. Then, authorities from both countries come to the scene for the autopsy. An autopsy made has been transferred as follows: "We would go to Syria very often from the hospital for autopsy. Of course, the smugglers would pass through the border, they would get wounded in the border, and then they would die. As the prosecutor and the doctor, we would go to Qamishli for autopsy. We went to the Qamishli area so many times. For example, the smugglers would go and they would say they are from Turkey. They had Turkish identities. They were coming too; we would do the autopsy with Qamishli's prosecutor and doctor. After that, they would send the funeral to Turkey. The Syrians, they were killed here, on the border, too. They also had poor people who would cross the border. Their home was there; they were bringing the goods here and taking goods from here. Actually, there was not much here for them. Acorn, oak tree they needed they were foreign stuff. There was nothing else in Turkey. Make sure 2 Syrians were killed at the border 20 years ago. As they were passing, they were ambushed. In the morning we went to the autopsy. It was about 9 o'clock. It was 11 o'clock when we made the autopsies and wrote a report. It was June, so hot Their skulls were torn. After that, they said "Let's go." said, "I will not come." The doctor said, "What are you going to do, let's go. It is hot." I said," "I will not go till I sew their heads. I won't leave them in this state. You go." Because they are Syrian, they will go there and say "Come see what the Turks did." For example, the parents will see. They have also stayed. They sat in the shadows of the car. I drew the skin to their face and saw. They took them like that. They were raked with Kalashnikov. No, it would not be a problem to bring the funerals. For example, on the Syrian side, while someone from Turkey was crossing the border, either a Turkish or a Syrian soldier shot him; he has been killed. Then an order said, "A Turk is killed on the frontier." Back then we were going, and they were coming We were doing an autopsy. It was not a crime to cross the border then" (From Nusaybin, male, 70 years old).
}

waiting in ambush, he would bend his head down and during the gunfight no one would get killed easily. The bullets would hover in the air. No one died in my guide but 2 people got wounded. I saved them. One of them was my uncle; the bullet had found his knee. We took him to Batman where there was a doctor. Another time, we had 5 carriers and we two were armed. The carriers were gone and we were sitting on the wire. We were hiding from the soldiers. They were gone, and the moment we stood up, the soldiers opened fire at us. In their first shoot my friend fell to the ground. He got shot on both legs. We called back the carriers; one of them came and took my friend and I clashed with them. I fired back a couple of bullets and it was a close call. So I saved the two. Ihad 7 meters of fabric with me to be taken to a woman. I cut it into two and wrapped them around both his legs tightly. In the morning we went to see a doctor who was an acquaintance, of course. The doctor said "whoever wrapped this must be a better doctor than me." I mean, if I hadn't wrapped it that way, he would bleed to death for sure. The doctor treated him and he got well after 20 days. The hospital wouldn't do; they would catch him immediately.

Identification of the dead or wounded smuggler in the gunfights means the unravelling of the partnership or the network that was set, or the suffering of the family of the smuggler from oppression. For this reason, the precautions taken for the maintenance of the secrecy of the identity of the dead or wounded smugglers have been transferred in one interview as follows: ${ }^{9}$

The son of my father's aunt was killed while smuggling. They killed him on the Syrian side. I was very young then. Back in those days, there was no getting across the doors; they would always get across the wires. One night, he was shot and wounded. His friend who was with him carried him on his back as far as his relatives in Syria, but he passed away there. The relatives burned the clothes of the two so that the soldiers would not recognize them. Later, the soldiers did not let them bring the corpse to this side. Only my father went to his funeral; no one else did. They buried him there. We were kids then. We don't know the exact place of the grave, but the relatives in Syria do. (from Nusaybin, female, in her 60s).

Aga: $\mathrm{He}$ is the person who receives a percentage although he is not involved in any matters such as the capital or effort investment for the trading in question. Özgen [14] divides the role of the agas in this trading into two periods. In the first period which encapsulates the years between 1938 and 1952 the agas have a small amount of share from the goods that was being brought or taken in the trade which was being dealt in the aga villages. The share that aga gets from the pass is more of a domination share than a share pointing to the real price of the good. In the period between the years 1952 and 1975 agas raised the percentage that they get without increasing the amount of the protection they

\footnotetext{
${ }^{9}$ A similar example was given place in the Milliyet Newspaper. According to the news on the paper, there had been a gunfight between gendarme and the smugglers, and the smugglers had torn the faces of their killed friends so that they would not be recognized. [20]
} 
provided:

We passed through the village under the Silk (Road) for 10 times. There was a school there. It was the summer time. No one was at the school. There was only a watchman with whom we had an agreement. We had his permission. There were two soldiers there who would change the angle of the camera. We took goods out of there for 10 times. It was about 8 years ago. We have a partner in that village who is the aga of the village. We had made the aga's son our partner. Yet, he was sitting at home and we were paying him his share. His profit was not much. We were eight people, he was the ninth. We were dividing the profit into nine.

In the past certain agas were the owners of the village. For example, he would water the gardens and the fields of each house in the village, freebie. Those agas would say to those who smuggled "if you don't pay my share, you can't work here." When the border wire was strung, there were agas; now there aren't. They wouldn't smuggle. But when I did, the aga who was the owner of the village would come; he was from Mala Berekata. He would come in the morning and say "I am hungry, yet you bring your load." But I was cunning; for example, I would get across 100 horses, yet I would show him only 10 of them. I would say "in the name of God, I got across 10 horses; this is the money for 10 horses." It had to be this way. I was undertaking this risk at the cost of my life and he would ask for money for free.

As a conclusion, the smuggling between Nusaybin and Qamishli has an organization based on ethnic origins and kinship. Ethnic networks and kinship ties make it possible for this economic form to be carried out with safety and profit. However, while the increase of danger in the border crossings brought forth the border guards and a group of merchants supported by the system of village ownership [14], it weakened the function of the kinship ties in large-scale smuggling.

\subsection{Suitcase Trading: "The Ants"}

The words "There is noone who has lived in Nusaybin and has not been involved in smuggling" summarizes the intensity of trade between the two cities. Smuggling started with portage, continued with a large-scale smuggling and nowadays it is mainly suitcase trading. A lot of people, including women, obtaining a passport with the lifting of the visa requirements between the two countries, have caused the suitcase trading to become widespread. The ones who use Nusaybin border gate to go across the border and carrying across border goods are called "ants" 10 by the customs

\footnotetext{
${ }^{10}$ The goods brought by the passengers were named suitcase trading because of the goods which were brought in suitcases and sold for the first time in the 1960s from the North Cyprus Turkish Republic. In the 1990s, this trade was called "shuttle trade," which the Russians made, continuously travelling between Turkey and Russia. [21] A similar local definition is the
}

officers.

One of the occupational groups that you can only see by the border gates is smugglers. The smugglers are people who do this as an acquired profession and do nothing else. Even though they are wealthy and they do not need to work, they acquired this as a profession, these guys smuggle. Every kind of smuggling. Whether they profit or not, it is their profession. Every morning they will come to the gate, go across the border, whether they bring goods or not, they will go and come back. Whether for profit or loss, it is a habit. As the guards and inspectors of our customs office call them, the ants. They go and come back every day; they walk that route every day (Arab from Nusaybin, 27 years old).

Regulation on customs in Turkey has been formulated by law no. 1918 dated 7.1.1932. This includes the definition of smuggling, punishment for smuggling, and the way in which seized goods are stored or the destruction of the seized goods. In the related legislation established to support the customs law, there are provisions regarding the nature of the goods and the passage of the goods which are used in commerce. The amount of goods can be brought along with passengers by the suitcase trade, which is the goods brought together with passengers for commercial purposes, is also determined by legislation.

The quota for the goods that can be brought with the person also determines the amount of ant trade that takes place during the day-to-day border crossing. Therefore, these regulations often adversely affect this form of trade, which is the source of many people's livelihoods. These restrictions that change from period to period, are considered as the state's attempt to break the relationship between Nusaybin and Kamishli:

If there was a gate here, 5 people that come and go, there would be trade. I mean, folks would get what they spent; 30-40 million would suffice. They don't let that happen, the gate is closed. For example, in Habur, a profit of something like 70 million is left to them. Here you can't even get 10 million. For example a guy says "15 million a day would be enough." But they don't let that happen, I mean they even set their eyes on 1 kilogram of tea. It's the district governor and the governor himself. They are trying to break up the connection. In the old days 1000 people would come and go. Of course all of these come and goes were border trade. Not with the trucks but with automobiles; they would have bought every kind of souvenirs. Like Habur border gate. Now they cannot do it. The folk cannot go (Male, from Nusaybin, 65 years old).

Donnan and Wilson [8], who defined the economic relations on borders as destructive for the states, underline that the state cannot control it no matter how hard it tries.

"underarm" smuggling, used by the border guards in Ghana. [9] 
Hence, the state makes concessions about destructive economy. One of these concessions is to pragmatically admit that a certain amount of infiltration of the border is inevitable. Otherwise, that is, when the state brings restrictions, it would encourage the smuggling. [9] Thus, crossing the border gates reduces border permeability and smuggling in the general sense. In this context, legal border trade and suitcase trading point out a controlled border crossing and trading.

Furthermore, when compare to other forms of border trade, suitcase trading is small on scale and since it is controlled on border gates, it is partially official. It is partially official, because states allow a certain amount of goods as the aforementioned example explains. Still, the local people try to smuggle more that the allowed amount. The traded goods change, depending on the period:

The goods they brought change. Locks, what can I say, things like toys and other stuff they used to bring but now they bring fruit, vegetable, sugar. People can get their passports nowadays but in the past it was weekly. You could only go once in a week. Sometimes they let you bring a lot of goods, sometimes they did not allow anything. If there was a fight, they mostly did not allow anyone. For example, they take someone's goods, they control those goods and stuff, sometimes the cops tear the bags with knives, the owner takes it hard; these guys are tired and angry already so they fight. At that moment they close the border gate, do not let the goods into the country. But sometimes when no such problems are around people can bring as much as they want; tea, sugar, rice, I mean they bring most of the things that you can think of. For example, some people have brought illegal things; there was centrifuge, you know, the motors used to transfer water. Once I saw there was this lettuce crate, he put that machine under the lettuces and duck taped to cover it, brought it that way. I saw it while carrying his goods. So you see, there are multiple ways like this to transport illegal goods. They put these cigarettes between the paper tissues. They get the cigarettes out of their boxes and hide them between paper tissues. These tissues are both cheap and light, so it is not much of a problem. They bring gasoline. There was this guy who brought tea; they also used barrels to transfer gasoline as well. They got their agreements though. They brought tea constantly; with every come and go they brought 15-20 kilogram tea. Also, those who go with the car have brought back tobacco. Somewhere close to the motor they brought the tobacco out, I have seen once. They buy old cars to smuggle for example. They modify the tank of the car, go with the empty one and come back full. Gasoline is so cheap over there. I remember one person can bring two sacks of rice, sugar, tea, then this vacuum cleaner, its hose; you could bring all of these at one time. Now they don't let too many goods in. (Male, from Nusaybin, 22 years old)
Border trade - formal or informal forms - is a way of getting by for those who are unemployed. However, formal trade and large scale smuggling necessitate substantial amounts of capital or a more complex network of relationships. Suitcase trading generally emerges when these two are not present. However, there are also those who make this trade by developing good relations with border patrol. Due to the fact that the distance between Kamishli and Nusaybin is short, the border is crossed on foot and the goods which are brought are carried in bags. However, depending on the amount of the goods, some people use cars sometimes. The only form of border trade in which women are involved is suitcase trade. Suitcase trading cost less especially when the distance is short. Furthermore, because of the fact that the Turkish Lira is more valuable than the Syrian Lira the people of Nusaybin have more purchasing power in Syria. Hence, this form of trade is more profitable than the domestic trade.

It is difficult to say that suitcase trading has significant economic value for many people. The reason behind this is on both sides of the border, the goods which exceed the quota are more likely to be caught. For this reason, to bring more goods arguments often erupt between the border guards and suitcase traders. The way to overcome this problem is bribing - which means spending more than earning - or developing good relationships with customs officers.

During the fieldwork, a daily trip to Syria has been made, which has been accompanied by two women, one of whom is a tailor and the other one is a haberdasher, which has created the chance to observe the relations between the suitcase traders and state officers; between the suitcase traders and Syrian traders. Nergis, woman from Nusaybin, is 29 years old and a tailor. She used to buy the things she need for her shop such as cloth, mannequin, threads, clothe and ready wear from Kamishli. The other woman (Gülizar) is 30 years old, and the items needed for her shop have been usually purchased from shops in the Smugglers' Market. She has taken the passport to cross the border and shop, since she had had no acquaintances on the other side of the border she could only go when she has saved some money. She knows some tradesmen in Smugglers' Market in Nusaybin and she mostly had the chance to buy the things she need on credit.

On the day we would go to Syria, we arrived at the gate around $11.00 \mathrm{am}$. Nergis arrived before we did and crossed the border with his brother. Since the Turkish currency could be used in Syria we did not need to visit the exchange office. But it was not the same for those who came from Syria. At the Turkish side of the gate, after the passport control and before the exit stamp was impressed, 15 Turkish lira transaction stamp price was paid. After the exit, the Syrian police collected our passports before opening the gate. We waited for a long time, approximately 1 hour. After that they opened the gate and took the ones who would cross the borders in. This time a long waiting began for the entrance process. Gülizar said "if we have bribed them, we would have passed already". The higher number of middle-aged or above male population who wanted to enter Syria drew 
attention. Most of them did not have suitcase, etc. with them. There was a female officer at the Turkish side of the gate, but none on the Syrian side also drew attention. Syria policeman announced the names one by one and the ones whose name was announced has taken his/her passport and enter Syria. When we entered Kamishli, we realised that the settlement was not as side by side with the border as Nusaybin, still, it was a walking distance. There were taxies at the gate. Gülizar said that we should haggle before hiring a taxi or they would charge us more than the usual rate because of the fact that we are foreigners. Taxi driver was talking Kurdish and accepted to take us to city centre for 3 liras.

The market which was called $s u k^{11}$ was very crowded and it seemed possible that you could almost find every product. Also, the market was divided into ethnic and religious parts like Turkish market, Christian market. Jobs were also classified according to ethnicity. For example most of the peddlers and tradesmen were Kurdish, jewelers were Christian, there were few Arabic tradesmen. All people we talked to at the market, including the Christians, could talk Kurdish. Most of them indicated that they knew it because their origins were in Turkey and the others said it was necessary for them to know Kurdish because of the trading with Nusaybin. We met with Nesrin and shopped together. Nesrin knew most of the Kurdish tradesmen in the market. His brother was a trader and Nesrin was using these connections of her brother. After she bought mannequin, child dress, wedding dress, evening dress, and clothe for her store, she bought the items ordered for the household. Her shopping list was quite loaded and she bought some of the items on credit. On the other hand, Gülizar bought everything with cash since she had no connections. She bought children's hat, clothe, ornaments, makeup products for her shop as well. But Gülizar purchased less than Nesrin. This was because of the fact that Nesrin had acquaintances on the border gate; her car was not even searched. But Gülizar - whose goods were confiscated at the gate before was cautious and shopped after calculating the risk that she could take. After shopping for their stores, we shopped for the households. We purchased tea, sugar and bairam candy and wafers. Gülizar paid attention as well to shop from Kurdish traders. They were especially cautious while buying tea, because it was emphasised that while passing the gate the officers were mostly onto tea, sugar and cigarettes. Hence, since there was a 1 kilogram quota on tea, we only purchased 1 kilogram tea per person.

We came to the gate towards the evening. The Syrian police was investigating bags and suitcases. The main problem for the ant traders who are crossing the border starts at this point. Border patrol to those who exceeded the quota especially tea and cigarette were the main concerns of quota violation - were very harsh and they battered the person who violated the quota, including women. For example, a woman was trying to cross the border with 6 kilograms of tea. But

\footnotetext{
${ }^{11}$ Arabic in origin, Sugh, was transformed into suk in Kurdish.
}

Syrian police did not let her pass and confiscated her tea. Bribe was given openly. Again, an incident which was observed, a man who came with a heavy load of goods gave 5 liras to Syrian police in front of everyone and crossed the gate. Also the police searched people as they deem fit. Lucky ones crossed the border to Turkish side without getting their goods confiscated. One of those was a woman of 70 years of age. The woman indicates that she has no one to take care of her so she has to look after herself by going to Kamishli 2-3 times. She purchased tea and cigarettes, she added that she is lucky to not get confiscated but she had very hard time crossing the border.

As there are traders going from Nusaybin to Kamishli, there are also traders who are coming from Kamishli to Nusaybin for suitcase trading. Since most of the goods in the domestic market are from Kamishli, the traders who are coming from Kamishli deals with goods which are rare or not present at all in Syria. For example, the goods such as stove, blanket, electrical blanket, pan, pot, butter, oil are among the goods which are traded from Nusaybin to Kamishli.

While some of the goods that are brought to Nusaybin from the other side of the border can be used for their own stores as the two examples state, most of them are sold to Smugglers' Market and to other stores. Tradesmen sell those goods in domestic market after adding their own margin of profit.

As a result, local people's preference of ethnicity while trading and maintaining relationship with the customs officers, manifests itself as the condition of the social network. In this context, local people's relationship with both same ethnicity and social networks and social networks established with the state officials show that this kind of trade as a livelihood continues with social networks.

\section{Conclusions}

In this article, the relationship of smuggling and exchange between Nusaybin and Kamishli as two border towns that are separated with the drawing of different political borderlines and positioned as opposites is studied. The blood ties and ethnic ties between these two cities are the maintainers of continuation of this kind of trade despite all of the risks. The reasons behind the smuggling between Nusaybin and Kamishli can be summarized as such:

1. The traditional trade and market places are consistent areas;

2. There are blood and ethnic ties with the other side of the border;

3. In Kamishli, which was founded by the French mandate as an alternative for the Nusaybin, the smuggling was encouraged by the mandate to develop Kamishli as a trade hub. As it was stated in the previous parts, the French founded Kamishli, which soon became a trade centre, after the border agreement between the French and the New Turkish 
state which left important trade hubs under Turkish rule. During the mandate there were high tax rates especially for the goods which were sent to Turkey, hence, the French officers encouraged smuggling which helped the trade of the town to develop. By this way, in a few years Kamisli became a rival to Nusaybin town of Turkey and replaced it as an important grain export center.

4. Lastly, the economic opportunities of a border region can be given. While border trade, together with the grand scheme of smuggling, develop a different style than traditional exchange pattern, on the other hand caused a class structure to appear in the society. Today, it is indicated that, those who are described as "the rich people of Nusaybin" have gotten rich through either grand smuggling or through other possibilities that the border brings (Such as having a store in Smugglers' Market, holding estates close to the border). Hence, grand smuggling is seen as a way to get rich. The appearance of the new "rich people" encourages most people to do this kind of trading.

As a last word, the border regions, despite hesitant economic policies of the states, provide important economic opportunities. The kinship and ethnic ties with the other side of the border are important for the continuation of this economic form and to turn this process into opportunities.

\section{REFERENCES}

[1] ÇEVİK, Adnan. "Orta Çağ İslam Coğrafyacılarına Göre Nusaybin.” Geçmişten Günümüze Nusaybin içinde. Sempozyum Bildirileri 27-28 Mayıs 2004. Edt. Kenan Ziya Taş. s. 65-76. 2009.

[2] ÖZGEN, Neşe. "Border Town Sociology 2001-2004" unpublished project.

[3] TOPRAK, Zafer. "Türkiye Tarımı ve Yapısal Gelişmeler." Türkiye'de Tarımsal Yapılar (1923-2000) içinde. Der. Şevket Pamuk-Zafer Toprak. ss. 19-36. Yurt Yay. 1988.

[4] KARPAT, Kemal H. Ortadoğu'da Osmanlı Miras1 ve Ulusçuluk. Recep Boztemur (Çev). İmge Kitabevi Yay. 2001.

[5] BRUINESSEN, Martin van. Kürdistan Üzerine Yazılar. İstanbul: İletişim Yayınları, 3. Bsm. 1992.

[6] BEŞİKÇİ, İsmail. Doğu Anadolu'nun Düzeni-Sosyo/Ekonomik ve Etnik Temeller. E Yayınları.
1969.

[7] AYDIN, Suavi.-Kudret Emiroğlu-Oktay Özel-Süha Ünsal. Mardin Aşiret-Cemaat-Devlet. Tarih Vakfı Yay. 2001.

[8] "Syria confiscates Turkish lands"” Milliyet Newspaper, 13.05.1965, p. 3.

[9] DONNAN, Hastins\&T.M. Wilson. Sinırlar-Kimlik, Ulus ve Devletin Uçları. Çev.: Zeki Yaş (Çev.). Ütopya Yayınları. 2002.

[10] BAUD, Michiel\& Willem van Schendel. "Toward a Comparative History of Borderlands" Journal of World History, Volume 8, Number 2, pp. 211-242. 1997.

[11] SIKDER, Mohammad Jalal Uddin. "Livelihoods and Informal Trade at the Bangladesh Border". Translated by Barun Kumar SARKAR, Inter-Asia Cultural Studies, Volume 6, Number 3, pp. 432-445. 2005.

[12] YEĞEN, Mesut (1996): "The Turkish State Discourse and the Exclusion of Kurdish Identity". Middle Eastern Studies, Vol. 32, No. 2. pp. 216-229. 1996.

[13] BRUINESSEN, Martin van. Ağa, Şeyh ve Devlet. Banu Yalkut (Çev.), İstanbul: İletişim Yay. 2003.

[14] BOZARSLAN, Hamit. “Çağdaş Türkiye'de Kürt Sorununun Yönleri”. Yavuz Alogan (Çev.). Kreyenbroek-Sperl (Ed.). Kürtler (Güncel Bir Araştırma) içinde (s. 100-118). Cep Kitaplar1. 1994.

[15] SCHENDEL, Willem van. "Easy Come, Easy Come: Smugglers on the Ganges." Journal of Comtemprary Asia, 23: 2, pp. 189-213. 1993.

[16] ÖZGEN, Neşe. "Sınırın İktisadi Antropolojisi: Suriye ve Irak Sınırlarında İki Kasaba". Gelenekten Geleceğe Antropoloji içinde. Haz. Belkıs Kümbetoğlu-Hande Birkalan Gedik. ss. 100-128. Epsilon Yay. 2005.

[17] ÇAPIN, Halit. "Yezidis and Bandits in the East", Milliyet Newspaper, 17.03.1962, p. 3.

[18] Milliyet Newspaper, 04.11.1975, p. 3.

[19] GOLUB, Stephen \& Jamie Hansen-Lewis. "Informal Trading Networks in West Africa: The Mourides of Senagal/Gambia and Yoruba of Benin/Nigeria." Nancy Benjamin-Aly Mbaye (Ed.). in the Informal Sector in Francophone Africa: Firm Size, Productivity and Institutions. pp. 173-194. 2012

[20] Milliyet Newspaper, 20.04.1974, p. 6.

[21] KIRCI, Murat. Türkiye'deki Bavul Ticareti Gelișmeler ve Yeni Alternatifler. M.Ü. Sosyal Bilimler Enstitüsü, İktisat Anabilim Dalı, Uluslararas1 İktisat Bilim Dalı. Yayınlanmamış Yüksek Lisans Tezi. İstanbul: 2007.

\footnotetext{
${ }^{\mathrm{i}}$ This study consists of a simplified and rearranged part of the doctoral thesis presented to the Department of Anthropology at Hacettepe University in 2013 , which deals with the effects of the nation-state borders on ethnic continuity.
} 